\title{
Assessment of Gender Participation in Rice Production in Abakaliki, Nigeria
}

\author{
Edeoghon, C.O. ${ }^{1} \quad$ Iyilade, A.O. ${ }^{2} \quad$ Nwachukwu, C.G. ${ }^{3}$ \\ 1.Department of Agricultural Economics and Extension Services, University of Benin, Edo State, Nigeria. \\ 2.ARMTI, Ilorin, Nigeria. \\ 3.Department of Agricultural Economics and Extension Services, University of Benin, Edo State, Nigeria.
}

\begin{abstract}
The study investigated the participation of male and female in rice production. Abakaliki Local Government Area was purposively selected because of its dominance and popularity in rice production. A total of hundred and sixty (160) male and female respondents were randomly selected from registered rice producers. Primary and secondary sources of instruments were employed and data were analyzed using descriptive statistics as frequency counts, percentages mean and standard deviation. T-Test and Product Moment Correlation was used to test the hypotheses. The result of the study showed that female farmers participated more in rice production chain than males in the study area. Activities like weeding, threshing, winnowing, cleaning, parboiling, dehusking etc. were dominated by the female farmers. Educational qualification $\left(\mathrm{r}=-0.323^{* *}, \mathrm{p}<0.139\right)$ had a negative correlation which implies that the less educated participated more in rice production activities. It is therefore recommended that whenever there is the need to build the capacity of rice farmers, female farmers should be trained in simple/local languages that they can easily comprehend in the study area since they are not as educated as their male counterpart.
\end{abstract}

Keywords: participation, gender, rice production, Abakaliki.

DOI: $10.7176 / \mathrm{JBAH} / 9-12-04$

Publication date:June $30^{\text {th }} 2019$

\section{Introduction}

In Africa, rice Oryzaglaberrima has been cultivated for 3500 years, between 1500 and $800 \mathrm{BC}$ it was propagated from its originated centre, the Niger River Delta, and extended to Senegal. Its cultivation declined in favour of the Asian species, and spread westward (Maddox, 2006). African rice helped African conquer its famine of 1203 (NRC, 1996).

According to Food and Agricultural Organization, Nigeria produced 4.8 million metric tonnes in 2012. Rice is a major food staple and a mainstay for the rural population and their food security. It is mainly cultivated by small farmers where average holding is about $1.0-3.0$ hectares. Agriculture is an important source of employment for $87 \%$ of economically active women and $80 \%$ of economically active men (Blackden and Rwebangira, 2004). Ironically women are known to be more involved in agricultural activities than men in Sub-Sahara African (SSA) countries. Rice production involves a lot of agricultural activities carried out by farmers comprising of both men and women. The gender participation in its cultivation are clearly seen in the different stages of production from land clearing, tilling, weeding, planting, harvesting, transplanting, drying, cleaning, threshing, winnowing, packaging, storage, transportation etc. These operations are commonly dominated by a particular gender group due to some certain factors like laborious nature of the work, tradition or custom and lots more.

Food and Agricultural Organization (FAO) defines gender as "the relation between men and women both perceptual and material. Gender is not determined biologically, as a result of characteristics of either women or men, but is constructed socially. It is a central organizing principle of society and often governs the processes of production and reproduction, consumption and distribution. However as seen from the FAO definition, gender issues focuses on the relationship between men and women, their roles, access to and control over resources, division of labour, interests and needs. It is common knowledge that gender inequality is one of those issues encountered as it cut across different roles, norms, and values, govern the gender division of labour and gender distribution of resources, responsibilities, agency and power (Franklin, 2007). These are critical elements for understanding production levels amongst rural farmers.

Major importers of rice usually include Nigeria, Bangladesh, Iran, Iraq, Saudi Arabia, Indonesia, Malaysia, the Philippines, Brazil and some African and Persian Gulf countries. The local production of rice is estimated to be three million tonnes. The current demand amounts to five million tonnes (NAMIS, 2014). There is a demandsupply gap of two million tonnes per annum for rice in Nigeria. In common with other West African countries, Nigeria is actively promoting domestic production to bridge the gap between production and consumption. According to the Minister of Agriculture and Rural Developments (Adesina, 2013) revealed that Nigeria spends over N356 billion on yearly importation of rice, he as well stated that Nigeria is running a prodigal consumption pattern in the sense that she spends billions of naira everyday importing rice from Thailand and India when rice can be grown here. He made reference to the well branded and packaged rich such as (Abakaliki rice from Ebonyi state, Umza rice from Kano, Miba rice from Benue State and several other long grained parboiled rice which can 
favourably compete with any rice from India. Recent rice importation figures attest to the fact that rice is in high demand in Nigeria (Bello, 2007).

In Nigeria, agriculture is the most important sector of the economy from the standpoint of rural employment, sufficiency in food and fibre, and export earning prior to the discovery of oil. Agricultural sector is still the leading sector in Nigeria, citing economy. It provides direct employment to about $75 \%$ of the population (NBS, 2007). Presently, agriculture contribution to Nigeria Gross Domestic Product (GDP) is about 37.2\% (CBN, 2006). Globally, it is evidenced that one of the major problems confronting mankind in recent times is food crisis. Based on this premise, the following objectives were addressed.

1. To examine the socio-economic characteristics of the male and female rice farmers in Abakaliki.

2. Identify the participation of different gender groups in rice production.

3. Identify the problems faced by male and female rice farmers in the study area.

\section{Hypotheses of the Study}

1) There is no difference between the participation of male and female farmers in rice production.

2) There is no significant relationship between the socioeconomic characteristics of male and female rice farmers and their participation.

\section{Methodology:}

The study was carried out in Ebonyi State, Nigeria. Ebonyi State lies approximately with longitude $8^{0} 05^{\prime} \mathrm{E}$ and latitude $6^{0} 15^{\prime} \mathrm{N}$. Ebonyi rice (which is popularly known as Abakaliki rice) is a whole grain cereal, very rich in natural minerals and vitamins, grown and milled in Nigeria.It is produced in African soil with minimal risk of Arsenic contamination and all natural. It has low sugar, very rich in dietary fibre, magnesium, fatty acid etc.

Abakaliki Local Government Area was purposely selected because of its dominance and popularity in rice production. One hundred and sixty (160) male and female farmers were randomly selected from registered rice producers. Primary and secondary sources of instruments were employed and data was analyzed using descriptive statistics as frequency counts, percentages mean and standard deviation. T-Test and Product Moment Correlation was used to test the hypotheses.

\section{Results and Discussions}

\subsection{Socio-economic characteristics of respondents}

Table 1 shows age distribution of the respondents in the study area. A high proportion of female respondents (59.5\%) was within the ages 41-50 years and male respondents (48.3\%) were within the ages of 31-40 years with a mean age of 38.9. This is an indication that most of the respondents are in their productive age. Also females tend to stay longer in rice production while the male involvement declines as they advance in age. This agrees with the findings of Ayoola et al (2011) which says that the categories of rice farmers in the Northern Guinea are in their productive age and tends to disagree with the findings of Kebbeh et al (2003) who reported an average age of 47 years for rice farmers in their research on challenges and opportunities for improving irrigated rice productivity in Kaduna and Niger States of Nigeria.

4.1.1. Household size

Household size is an important source of family labour. A large household is capable of supplying all the labour requirement needed and rely less on hired labour.

Results in Table 1 shows majority of the respondents falls within household size of (6-10) with $54.8 \%$ and $50.0 \%$ of female and male rice farmers respectively with a mean of 7 perasons per household. This is an uneconomic household size for agriculture. This implies that rice farm households could rarely draw some family labour from their household that will be sufficient in rice production. Consequently, there will be an increase in production cost as a result of hired labour.

4.1.2. Educational Qualification

The result shows that a high proportion of the female $(35.7 \%)$ obtained only primary education and $(40.7 \%)$ of male had secondary education while $13.8 \%$ have no formal education; compared with a previous finding that about $29 \%$ of rice farmers in Kaduna and Niger State do not have formal education (Kebbeh et al., 2003). This implies that majority of the rice farmers in the study area have at least one form of formal education. This could aid the rice farmers in understanding the importance of adoption of innovations.

4.1.3. Farm Experience (Years)

The result reveal the highest years of experience to between (11-15) years for both the female and male with $38.1 \%$ and $45.8 \%$ respectively, followed by (16-20) with $31 \%$ and $32.2 \%$ for female and male respectively with a mean year of 13 years. This indicates long years of experience which is accompanied by improved practices, proper timing and better marketing strategies for produce. This conforms with Kebbeh et al., (2003), which found an average of 21 years of farmers' experience in rice farming in Kaduna and Niger States of Nigeria. 


\subsubsection{Size of Farm}

From Table 4.1, over half of rice farmers have farm size of 2.0 ha and below with $81 \%$ and $89 \%$ for female and male respectively with a mean of 2.0. The average farm size of the men is greater than that of the women. $38.8 \%$ of the farmers have farm sizes between 2.1- 4.0 ha. No farmer has a farm size above 6.0ha. This implies that farm units were generally small sized.

Nigeria makes it easily accessible by the males. This findings agrees with Edeoghon and Koledoye (2017) that the male farmers in Edo State had larger farm sizes than the female farmers. The probable reason for this trend as observed by Ajani (2008) could be patriarchal structures and authorities who give the heritage and control of land to men in Nigeria resulting in women having less access to productive resources particularly land.

Table 1: Socio-economic Characteristics of Respondents

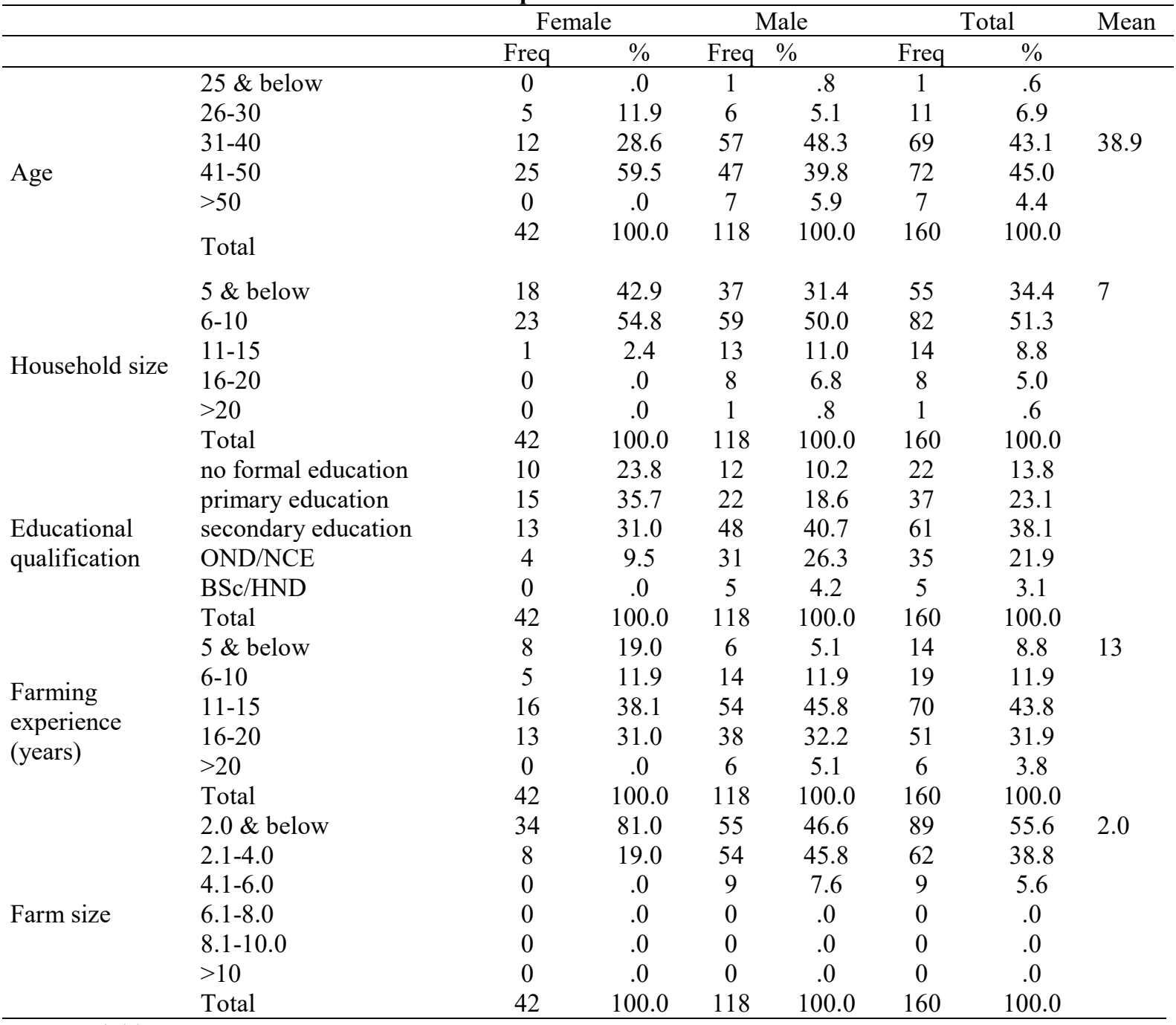

Source: Field survey, 2014.

\subsection{Participation by Gender Group in Rice Production}

Table 2 shows that high proportion of women participate more in land clearing, weeding, harvesting, threshing, winnowing/blowing and cleaning than their male counterpart. These operations are dominated by women. This may be as a result of the ease of operation or the meticulosity of the task. Men are generally known to have little patience and are quick in actions which makes them unsuitable for care-intensive operations.

Male and female rice farmers participated equally in parboiling, dehusking, packaging, storage, transportation and marketing.

The study reveals further that high proportion of men participate in tilling which is a very tedious exercise.

This conforms to the findings of Hills and Vigneri (2009), which says that men engage in more physically challenging work such as tilling and tree felling and women perform the less physically demanding work such as weeding and harvesting.

Women in Tanzania take charge of weeding, harvesting, processing, and storing food crops; they also contribute significantly to these tasks for cash crops, though men tend to help more with agricultural task for cash 
crops (Ellis, 2007).

Table 2: Participation by gender group in rice production

\begin{tabular}{lcccccc}
\hline & \multicolumn{2}{c}{ Female } & \multicolumn{2}{c}{ Male } & \multicolumn{3}{c}{ Total } \\
\hline & \multicolumn{2}{c}{ Yes } & \multicolumn{2}{c}{ Yes } \\
\hline Marketing & Freq & $\%$ & Freq & $\%$ & Freq & $\%$ \\
Transportation & 41 & 97.6 & 114 & 96.6 & 155 & 96.9 \\
Planting & 40 & 95.2 & 114 & 96.6 & 154 & 96.3 \\
Drying & 41 & 97.6 & 111 & 94.1 & 152 & 95 \\
Storage & 38 & 90.5 & 111 & 94.1 & 149 & 93.1 \\
Packaging & 38 & 90.5 & 111 & 94.1 & 149 & 93.1 \\
Parboiling & 34 & 81 & 111 & 94.1 & 145 & 90.6 \\
Tilling & 36 & 85.7 & 95 & 80.5 & 131 & 81.9 \\
Dehusking & 0 & 0 & 116 & 98.3 & 116 & 72.5 \\
Clearing & 42 & 100 & 74 & 62.7 & 116 & 72.5 \\
Threshing & 41 & 97.6 & 41 & 34.7 & 82 & 51.3 \\
Harvesting & 41 & 97.6 & 29 & 24.6 & 70 & 43.8 \\
Cleaning & 42 & 100 & 26 & 22 & 68 & 42.5 \\
Weeding & 41 & 97.6 & 25 & 21.2 & 66 & 41.3 \\
Winnowing/blowing & 42 & 100 & 15 & 12.7 & 57 & 35.6 \\
\hline Source: Find & 41 & 97.6 & 8 & 6.8 & 49 & 30.6 \\
\hline
\end{tabular}

Source: Field survey, 2014

\subsection{Constraints in Rice Production}

Table 3 shows the different constraints in rice production experienced by male and female farmers. Findings from the Table reveals preference or shift to foreign rice as a very serious constraint in rice production with (3.90) and (3.91) for female and male rice farmers respectively. This is followed by ineffective farm organization and groups (3.24) female and (3.35) male, adverse weather condition (2.68) female and (2.8) male and poor electricity (2.52) female (2.63). The dispersion of preference to foreign rice $3.91 \pm 0.87$ around the mean affects the significance of the mean positively thus the significance is very strong across the population. This implies that all the rice farmers in the study area agree that preference or shift to foreign (imported) rice is a constraint to rice production in the study area.

This is not in consistent with the findings of Matanmi, Adesiji, Owawusi and Oladipo (2011) which saw lack of rice processing machine (such as thresher and destoner) and financial constraints as the major perceived limiting factors in rice production in Patigi, Kwara State, Nigeria.

Table 3: Distribution of rice farmers showing constraints in rice production

Preference or shift to foreign (imported)rice

Ineffective farm organization and groups (Co-operatives)

\begin{tabular}{cccccc} 
& female & \multicolumn{2}{c}{ Male } & \multicolumn{2}{c}{ Total } \\
\hline Mean & SD & Mean & SD & Mean & SD \\
\hline $3.90^{* *}$ & .84 & 3.91 & .89 & $3.91^{* *}$ & .87 \\
$3.24 *$ & .93 & 3.39 & .94 & $3.35^{*}$ & .94 \\
$2.68^{*}$ & 1.28 & 2.80 & 1.25 & $2.77^{*}$ & 1.26 \\
$2.52^{*}$ & 1.20 & 2.63 & 1.20 & $2.60^{*}$ & 1.20 \\
2.14 & 1.29 & 2.18 & 1.37 & 2.17 & 1.35 \\
2.02 & .71 & 2.16 & .89 & 2.12 & .84 \\
1.97 & 1.00 & 2.12 & 1.10 & 2.08 & 1.08 \\
2.17 & .79 & 1.95 & .77 & 2.01 & .78 \\
2.03 & 1.08 & 1.94 & .91 & 1.97 & .95 \\
1.87 & .42 & 1.99 & .48 & 1.96 & .47 \\
1.81 & .74 & 1.98 & .74 & 1.93 & .74 \\
1.90 & .78 & 1.93 & .68 & 1.92 & .71 \\
1.76 & .43 & 1.94 & .73 & 1.90 & .67 \\
1.83 & .79 & 1.92 & .72 & 1.89 & .74 \\
1.78 & .52 & 1.84 & .63 & 1.82 & .60 \\
1.67 & .48 & 1.84 & .58 & 1.80 & .56 \\
1.68 & .50 & 1.60 & .62 & 1.62 & .59 \\
1.10 & .30 & 1.05 & .22 & 1.06 & .24 \\
\hline
\end{tabular}

Adverse weather condition

Poor electricity

Poor extension services

Inadequate farmland

Scarcity of inputs

Inadequate labour supply

Poor transportation facilities

Unavailability of fertilizer

Poor storage facilities

Poor storage facilities

High cost of processing

Lack of storage facilities

Labourious nature of work

Inadequate processing facilities

1.10

Source: Field survey, 2014 


\subsection{Hypotheses}

4.4.1. Difference in the Participation of Male and Female Farmers in Rice Production

Result from Table 4, shows that the difference in participation of male and female farmers in rice production is highly significant $(\mathrm{t}=18.17)$ with male $(\bar{X}=9.42)$ and female $(\bar{X}=13.38)$ and a mean difference of (3.957). The female farmers participate more in rice production chain than males in the study area. Activities like weeding, threshing, winnowing, cleaning, parboiling, dehusking etc. are dominated by the female farmers. This does not agree with the findings of Afolami et al (2012) which says that majority of rice producers in Ekiti (90.3\%) and Ogun $(85 \%)$ States were males suggesting a high dominance of male farmers in rice production.

Table 4: Difference in the participation of male and female farmers in rice production

\begin{tabular}{lcccc}
\hline \multicolumn{1}{c}{ Sex } & $\mathrm{N}$ & \multicolumn{2}{c}{ Participation score } & \multirow{2}{*}{ D } \\
\cline { 3 - 4 } & & Mean & Difference & \multirow{2}{*}{3.957} \\
\hline Male & 118 & 9.42 & 3.17 \\
Female & 42 & 13.38 & &
\end{tabular}

* Significant at the 5\% level (critical $t=1.96$ )

4.4.2. Relationship between socio-economic characteristics of male and female farmers and their participation in rice production activities

The results in Table 5, shows that there is a significant relationship between educational qualification, farm size and sex with their participation in rice production.

Educational qualification: $\left(\mathrm{r}=-0.323^{* *}, \mathrm{p}<0.139\right)$ had a negative correlation which implies the less educated participated more in rice production activities. This could mean that women who participated more were not as educated as their male counterparts.

Farmsize: $\left(\mathrm{r}=-0.200^{* *}, \mathrm{p}<0.139\right)$ had a negative correlation which implies that the higher the farmers farm size, the lower the farmers' participation. This could be as a result of the need for more use of hired labour with regards to the large farm size.

Sex: $r=-0.762 * *, p<0.139$ ) had a negative correlation. This implies that the gender of the farmer affects the different areas of participation in rice production. More female farmers were observed (Table 2) to be involved in some areas of participation e.g. weeding, threshing etc, while lesser male farmers participated in same areas.

The negative values of household size and years of experience, though not significant meant that smaller household sizes and new entrants of rice farming enterprise participated more in production activities. This could be because the new entrants ventured rice farming with a vision to be market oriented and commercialize. This result agrees with Edeoghon and Oria-Arebun (2011) where they observed negative correlation of length of residence and household size in economic empowerment of urban agriculture among women farmers in Edo State. Table 5: Relationship between socio-economic characteristics of male and female farmers and their participation in rice production activities

\begin{tabular}{|c|c|}
\hline \multirow{2}{*}{ Independent variables } & Participation score (total) \\
\hline & Coefficient (r) \\
\hline Age & 0.027 \\
\hline Educational qualification & $-0.323^{* *}$ \\
\hline Farm size & $-0.200^{* *}$ \\
\hline Household size & -0.122 \\
\hline Years of experience & -0.05 \\
\hline Sex & $-0.762^{* *}$ \\
\hline
\end{tabular}

*Significant at the 5\% level (critical $r=0.139$ )

\section{Conclusion and Recommendations}

A higher proportion of young females with mean age of 38.9 years having a mean household size of 7 years were involved in rice production; having a form of formal education or the other. Farm units were generally small with a pooled mean of 2 hectares. Female farmers participated more in rice production chain than males in the study area. Activities like weeding, threshing, winnowing, cleaning, parboiling, dehusking etc. were dominated by the female farmers. Most serious constraints of rice farmers were consumer's preference for imported rice, ineffective cooperative groups, adverse weather conditions and poor electricity.

Educational qualification $\left(\mathrm{r}=-0.323^{* *}, \mathrm{p}<0.139\right)$ had a negative correlation which implies that the less educated participated more in rice production activities.

It is therefore recommended that whenever there if there is the need to build the capacity of rice farmers, female farmers should be trained in simple/local languages that they can easily comprehend in the study area since they are not as educated as their male counterpart.

It is also recommended that government and private sectors get involved in processing and packaging of rice so as to improve the quality of local rice hence, making it acceptable to consumers. 


\section{REFERENCES}

Adesina, O.S. (2013). Unemployment and Security Challenges in Nigeria. International Journal of Humanities and Social Science. www.ijhssnet.com.>journals>vol_3_no.7;April2013 Assessed 29/05/19.

Afolami, C.A., Obayelu, A.E., Agbonlahor, M.U. and Lawal-Adebowale O.A. (2012), "Socio-Economic Analysis of Rice Farmers and Effects of Group Formation on Rice Production in Ekiti and Ogun States of South-West Nigeria", Vol. 4, Pp 4.

Ajani, O.I. (2008), “Gender Dimensions in Agriculture, Poverty, Nutrition and Food Security in Nigeria Strategy Support Program (NSSP)”, IFPRI, Pp 5-7.

Ayoola, J.B., Dangbegnon C., Daudu C.K., Mando A., Kudi T.M., Amapu I.Y., Adesun J.O. and Ezui K.S. (2011), "Socio-Economic Factors Influencing Rice Production Among Male and Female Farmers in Northern Guinea Savanna Nigeria: Lessons for Promoting Equity in Action Research”, Pp 1011-1013.

Bello, N.J. (2007). Extreme Weather and Climate Events: Implications for Water Resources. Proceedings of the International Conference of the Nigerian Meteorological Society, November 2007. Pp $46-57$.

Blackden, P. and Rwebangira, O. (2004). Case Studies of Women in Tanzanian Agribusiness - Wilson Centre. http://www.wilsoncenter.org<sites>files Assessed 29/05/19.

CBN (2006), "Central Bank of Statistical Bulletin".

Edeoghon, C.O. and Oria - Arebun (2011). Urban Agriculture as a Measure of Women Economic Empowerment in Ovia North East Local Government Area of Edo State, Nigeria. International Journal of Agricultural Economics and Extension Services. Vol 1 (1). Pp 109 - 119.

Edeoghon, C.O. and Koledoye, G.F. (2017). Involvement in Non - Farm Activities and Occurrence of Domestic Conflicts Among Rural Farmers in Edo State, Nigeria. Nigerian Journal of Rural Sociology. Vol 17 (1). Pp $37-44$.

Ellis, A. (2007), "Gender and Economic Growth in Tanzania”, The World Bank: Washington, D.C.

Franklin, S., (2007), "Gender Inequality in Nigeria. http://www.tigweb.org Assessed 30/05/19.

Kebbeh, A., Haefele, M. S. and Fagade, S.O. (2003), "Challenges and Opportunity for Improving Irrigated Rice Productivity in Nigeria", Abidjan: WARDA.

Maddox, G. (2006), "Sub-Saharan Africa: An Environment History”, ABC-CLIO.P. 267.ISBN. 1851095551.

Matanmi, B.M., Adesiji, G.B., Owawusi, W.O. and Oladipo, F.O. (2011), "Perceived Factors Limiting Rice Production in Patigi Local Government Area of Kwara State", Journal of Agriculture and Social Research (JASR) Vol.11, No 2, Pp 6

NAMIS (2014), "Nigeria Agricultural Marketing News Bulletin", No.4. www.afmin.net

NBS (2007), "National Bureau of Statistic: Agriculture Survey Report 1994-2006. Produced under the Auspices the Economic Reforms and Government Project (ERGP)", Pp. 60-71.

National Research Council (1996), "African Rice” (http://books.nap.edu/openbook. phb?record id=2305\&page=17), Lost Crops of Africa: Volume 1: Grains (http://books.nap.edu/openbook.php?record_id $=2305$ ).

Vigneri, R. (2009). Diabetes Therapy and Cancer Risk. - NBCI. http://www.ncbi.nlm.nih.gov>pubmed. Assessed 29/05/19. 